\title{
Barriers and Facilitators of Front Identification in China's Pork Traceability System
}

\author{
Honghua Chen and Fen $\mathrm{Xu}^{\mathrm{b}, \mathrm{c}, 1}$ \\ ${ }^{a}$ College of Economics and Management, China Agricultural University, Beijing, \\ China \\ ${ }^{\mathrm{b}}$ School of Economics, Beijing Technology and Business University, Beijing, China \\ ${ }^{\mathrm{c}}$ School of Economics and Management, Tsinghua University, Beijing, China
}

\begin{abstract}
The identification is the sole carrier of the whole-process information of the pig traceability system. The front identification is the first component, an indispensible part of the proper traceability of the product. This paper conducts in-depth study on company B, company S and company Z from Beijing, Shandong and Zhejiang to understand their specific management process, cooperation model and interest allocation, identification method, willingness to implement, the cost and benefit before and after the implementation as well as the effect of the implementation. The Cannikin Law is also employed to conduct the comparison analysis on the implementation of the system, so as to set an example for the pig traceability system in other relevant companies of the sort. The results show that, the organization model plays the most important part in the front identification management, with "company + bases + farmers" as the most conducive mode for the implementation of front identification yet not prone to be promoted; "company + cooperative + farmers" is more apt to promotion. Other important impact factors of the implementation level of front identification in pig traceability system include the education level of the implementation subject, the scale and the location of the company.
\end{abstract}

Keywords pork traceability system; supply chain; front identification; cost-benefit analysis

\section{Introduction}

China takes the lead in the amount of pork stock, slaughter, and consumption, taking up half the production and consumption of pork products globally. Pork ranks at the top of the meat products consumed by Chinese urban residents, whose meat consumption is over $60 \%{ }^{2}$ of the total consumption in China. This brings its own substantial safety problems. In recent years, food safety incidents, such as clenbuterol contamination in the meat produced by Shuanghui, double-dead meat, and zombie meat, are haunting the Chinese market, with 13,278 incidents between 2005 and 2014 [1]. These incidents

\footnotetext{
${ }^{1}$ Corresponding author,Beijing Technology and Business University, 100048, No 11 Fucheng Road, HaiDian District, Beijing, China.E-mail: xufen@sem.tsinghua.edu.cn.In the process of writing this paper, the corresponding author also undertakes part of work of first author, so corresponding author is also the co first author of paper.

${ }^{2}$ Data source: Food and Agriculture Organization of the United Nations database.
} 
severely damage consumers' benefits, reducing their faith in purchasing and causing turmoil in China's economic development and social stability.

The traceability system, which can trace whole-course information of the supply chain, is widely deemed an effective method to eliminate asymmetric information on food safety, identify food safety risk and responsibility, and elevate food safety levels [2]. It has been adopted by several countries including France, the US, and Denmark. The pork traceability system now plays an active role in solving safety problems in pork and pork products [3]. The pork traceability system started relatively late in China and is still in its infancy, with great support and promotion from governmental authorities. In 2016, China's state council issued the 'Suggestions on propelling the development of traceability systems for important products' as guidelines for developing the product traceability system. In 2017, seven departments, including the Ministry of Commerce, Ministry of Agriculture, and General Administration of Quality Supervision, issued the 'Guidance on the development of informationized product traceability system', with the aim of establishing a nationwide, unified, open, advanced, applicative, synchronized, and informationized product traceability system by 2020 .

The pork traceability system depends on the identification to record, store, and inquire about key information from every link in the supply chain, including information on breeding, slaughter, processing, and sales [4-7]. When products are found with safety issues, the system's search function can help clarify the responsibility of relevant corporations in accordance with pertinent regulations and contracts to enforce targeted product recall and punishment on such corporations $[8,9]$.

The identification is the sole carrier of all the information of the pork traceability system [10,11]. It is the most important information management link of the traceability system. It is a process of labelling and identification that includes allocation of the identification number, labelling, identification document creation, registration in the central database, and identification of other changeable information. So identification is the basic carrier of information flow for the whole supply chain chased by the traceability system, and it connects consumers or governmental authorities with product information.

Front identification, as the first part of product identification in the pork traceability system is the carrier of farmers' pork breeding information during this process, not only determines the quality of pork products but also traces the problem's root cause, which is the weakest part of the supply chain [12].

In this context, this study examined the front identification issue of China's pork traceability system, covering the implementation status quo and important impact factors of front identification management in the system.

Existing studies on the traceability system had the following three characteristics. 1) they conducted basic research on the definition, features, and functions of the traceability system. 2) three major research methods were established: transaction cost analysis, cost-benefit analysis, and consumers' willingness to pay. 3) Some scholars focus on the development and application technology of the traceability system.

As regards the pork traceability system, many studies were conducted from the perspective of stakeholders' willingness to pay. Zheng et al. (2012) [13], Wu et al. (2016) [14], and Ying et al. (2016) [15]analysed consumers' preference and willingness to pay for traceable pork; Zhou et al. (2012) [16]and Wu et al. (2014) [17] studied the company and farmers' willingness to invest in the pork traceability system. Some studies provided improvement plans for this system [18,19]. Front identification, the weakest part of the pork traceability system, however, is left untouched with 
insufficient material and data.

This study contributes from the following three aspects. First, field research and in-depth interviews are employed to investigate front identification issues of the pork traceability system in companies B, S, and Z from Beijing, Shandong, and Zhejiang, respectively, with a grasp on primary data and information to enrich the database of domestic research on traceability systems. Second, new attempts are made from the supply chain management perspective to study front identification of the pork traceability system, thus expanding the relevant literature. Third, comparative analysis of multiple cases was conducted to study the implementation status quo, organization model, profit distribution, and willingness to implement, with greater representation and worth of promotion, thus serving as reference to other companies for implementing a pork traceability system.

\section{Theoretical basis of front identification in traceability systems}

The pork traceability system's objective is carrying information of every link of the supply chain. The system chases relevant information from breeding, slaughter, processing, and sales [20]. The front identification is the first component and indispensable for proper traceability of the product.

The Cannikin Law describes the importance and special position of front identification in the pork traceability system. According to the extended Cannikin Law, the capacity of a barrel depends on the compactness of the planks to avoid leakage, regardless of its size [21].

From the supply chain perspective, implementation of the pork traceability system involves every link of the supply chain. Presently, there exists a severe problem of the lack of product identification as the first link of the system, that is, of front identification. The system can only function normally if the problem is tackled properly.

Thus, ensuring effective synergy of the information from each link of the supply chain requires tracing the whole process of the pork traceability system. Incomplete front identification of pork creates a chasm of information between farmers and the pork butchers and processors, preventing effective realization of the traceability system.

\section{Methods and materials}

A multi-site, cross-sectional qualitative research design was employed to provide in-depth understanding of the barriers and factors influencing front identification in China's pork traceability system. Eligible participants included production managers, quality and safety supervisors, and policymakers. The study received ethical approval from the Bureau of Reclamation of China's Ministry of Agriculture.

The study employed several data collection methods, including focus group discussions, field notes, face-to-face interviews, and organizational document analysis on front identification of traceability systems. The focus group was conducted with eight government officers of the Bureau of Reclamation and face-to-face interviews with top managers of companies B, S, and Z from Beijing, Shandong, and Zhejiang, respectively. An interview guide with a series of open-ended questions was developed 
and pretested based on literature review and expert opinions [8,9]. The guide's main domains included questions about the front identification management process, cooperation model, interest allocation, identification method, willingness to implement, cost and benefit before and after implementing front identification, and effect of the implementation. On average, audio-recorded in-depth interviews with each participant lasted about one hour, while focus group discussions took about one and a half hours to complete. Overall, data from primary sources comprised 15 in-depth interviews with representatives of the three entities and focus group discussions with 12 respondents from governmental and non-governmental organizations (3-5 participants per group) conducted during March-July 2015.

Various research techniques were applied to ensure credibility and transferability of the study [22-24]. Credibility was reached through regular peer debriefings among research team members. Provision of detailed description of the study setting and sample characteristics (Figure 1) and the data collection and analysis process helped enhance the findings' transferability.

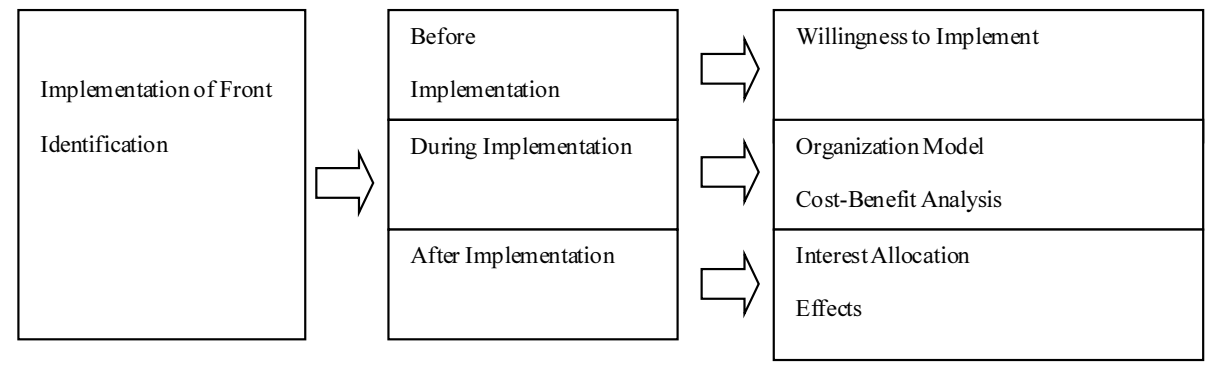

Figure 1. Impact factors of front identification implementation in China's pork traceability system while applying the supply chain theory

Source: Chen et al. (2017)

\section{Comparative analysis of three cases}

\subsection{Sample profile}

In the food sector, three respondent organizations have implemented front identification in their traceability system.

Company B (Beijing Black Pork Seed Stock Station) is a member of China's local pork protection and utilization cooperation group. In 2004, the company passed the authentication using the standardization system of the Beijing Municipal Administration of Quality and Technology Supervision.

Company S in Shandong was established in 1986 and has become a top national large enterprise group with fine breeding of pork, standardized raising, fodder production, veterinary drug administration and quarantine, pork slaughter, meat processing, and bioengineering.

Company Z in Hangzhou, Zhejiang province, was established in January 1998. This food processing company together performs the functions of pork slaughter, high/low temperature meat processing, logistics and delivery, and sales. 


\subsubsection{Status quo of front identification in company $B$}

The pork traceability system in company B was established in October 2009. The company is subordinate to Beijing Capital Agribusiness Group Northern Suburbs Farm and is among the second group of companies with a traceability system in the agricultural reclamation system (under the command of the Ministry of Agriculture's Bureau of State Farms and Land Reclamation).

This company possesses black pork seeding and breeding bases in Beijing. It is committed to independent seeding and breeding methods and covering the processes of seeding, breeding, creation of commercial pork product, slaughter, processing, delivery, and sale at an exclusive shop. Its black pork receives an ear mark, which will be used in the whole process within 12 hours of the pig being born. Thus, all the processes are within the control of the company and completed by the employees, except for the slaughter process, which is outsourced to the Beijing $5^{\text {th }}$ Meat Processing Plant (Figure 2).

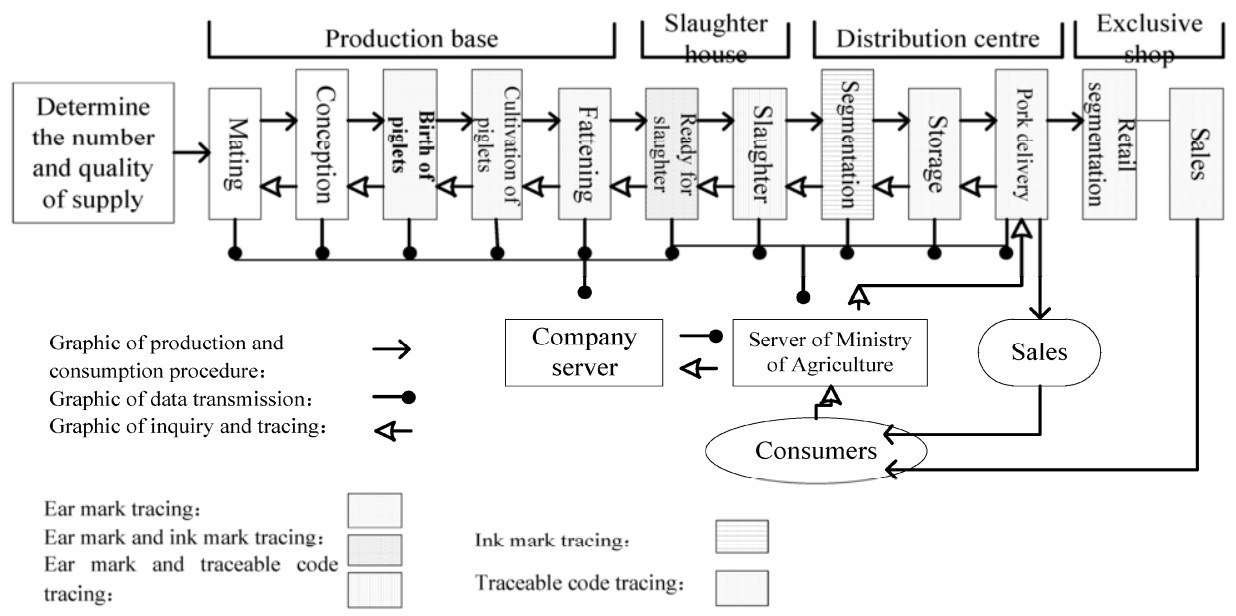

Figure 2. Flow diagram of the pig traceability system in company B

Data source: drawn by the author

The traceability system in company B employs the 'ear mark + ink mark' method. Black pork should receive an ear mark at the company's veterinary station within 12 hours after birth, as its sole identification.

There are two main stages in the front identification management of company B. Stage 1 is from the birth of porklets to pork being ready for slaughter. In this stage, it is possible to record information about each pork's feeding, medication, and management through its identification or ID, that is, the ear mark number. Figure 3 shows the structure of the traceability chain and relevant breeding information. 


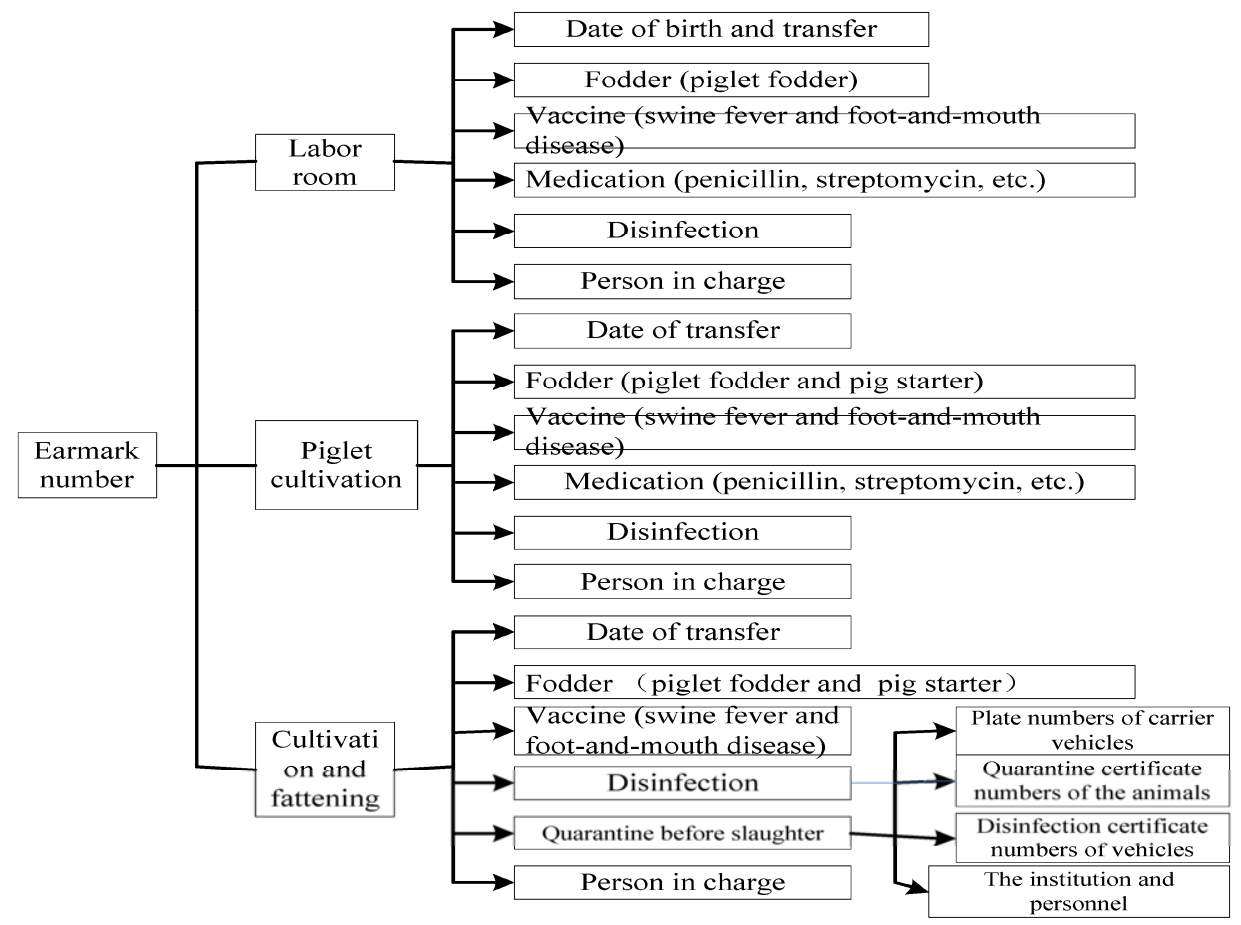

Figure 3. Structure of the traceability chain and relevant cultivation information in company B Data source: drawn by the author

Stage 2 covers the processes after the slaughter. When the pork is ready for slaughter, an ink mark is attached to both sides of the loin with a special tattoo hammer. Each pork carries both the ear mark and ink mark, and the latter is input into the traceability system database in the mapping table of ink and ear marks. The mapping table is submitted to the delivery centre within four hours after the slaughter, and records of the breeding bases are entered accurately. The number of pork for slaughter in every breeding base is uploaded to the database and its information is entered (Figure 3).

The slaughter is done by the Beijing $5^{\text {th }}$ Meat Processing Plant. Even after segmenting the pork into head and carcass, its ink mark will continue providing information for identification. Every black pork is packed completely in a labelled case with a traceable code, which proffers its detailed information to the staff upon delivery to the supermarket. The traceable code is run during storage and sales of the segmented product and made available to consumers, revealing every piece of the pork's front information, including the fodder and health condition, through inquiry of the identification code. However, presently, it is only possible to trace each pork instead of specific parts of the pork. Figure 4 provides information on the ink mark number, traceability code, and slaughter. 


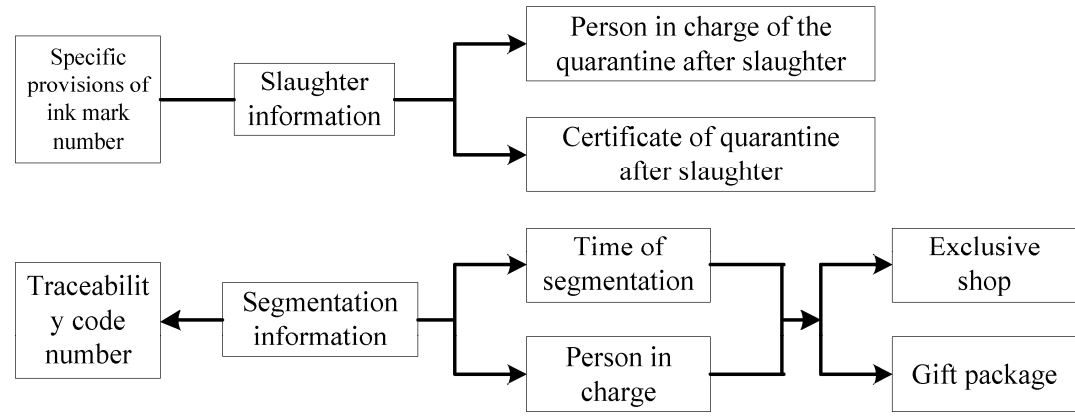

Figure 4. Information on ink mark number, traceability code, and slaughter for company B

Data source: drawn by the author

\subsubsection{Status quo of front identification in company $S$}

To guarantee the safety and quality of meat product from the source, company S adopts the 'company + cooperative + farmers' model and conducts 'six unified links' management with unified supply of boar, unified artificial insemination, unified fodder supply, unified veterinary drug administration and quarantine, unified technological service, and unified purchase of fat pork. Each farm conducts independent breeding and breeding in accordance with the regulation, operates closely, and benefits from purchase by the company at the conservation price.

Therefore, the pork traceability system in company $\mathrm{S}$ incorporates the following five parts: purchase, slaughter, processing, storage, and logistics. Information of the whole process is traced by an electronic ear mark through radio frequency identification devices (RFID). Company S also installed the safety traceability system in multiple hypermarkets for consumers to check detailed product information starting from the farm to the point of sale via traceability code scanning.

The electronic ear mark is a major type of individual identification of pork as it can trace each pork unit, and it also contains basic information of the farm. There are two stages in its front identification.

Stage 1 is from the birth of porklets to pork being ready for slaughter. Company S' 'company + cooperative + farmers' model requires farm employees to organize RFID ear-mark printing on pork within a certain period after the birth of porklets during the breeding process. Member farmers from each cooperative will keep a record in the breeding file for casual inspection of the cooperative on the completeness and authenticity of information and for collection of relevant information.

Stage 2 covers the processes after the slaughter. The RFID electronic label is attached to the slaughtering line; when qualified pork enters the slaughterhouse, its RFID ear mark information is transferred to the RFID electronic label information on the hook, enabling effective synergy between front and rear identification (Figure 5). 


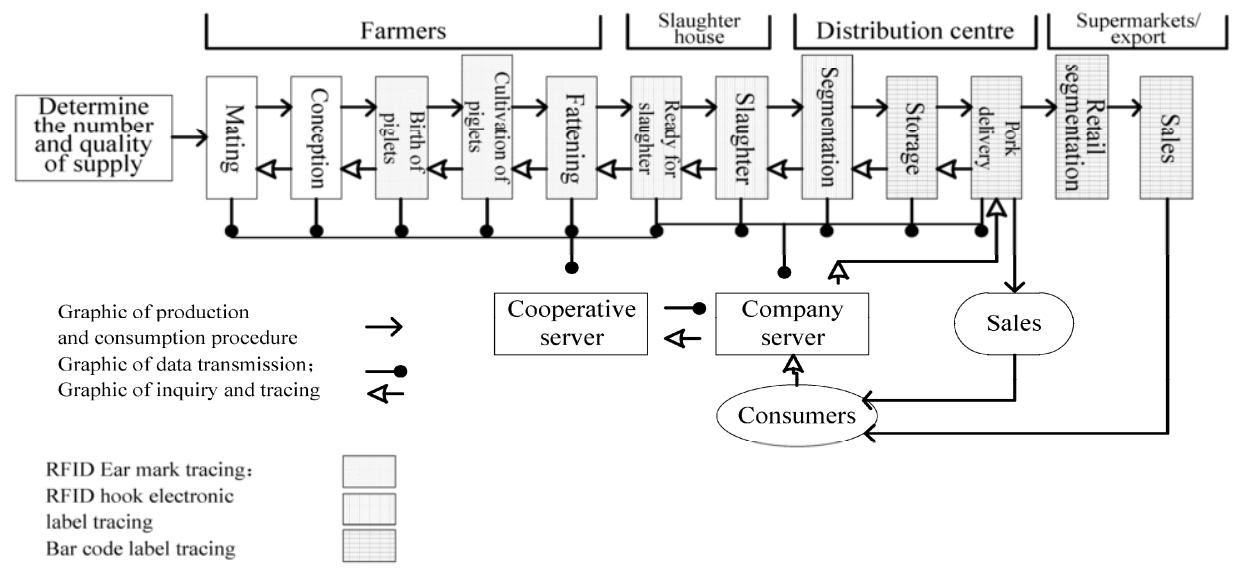

Figure 5. Flow diagram of the pig traceability system in company $S$

Data source: drawn by the author

\subsubsection{Status quo of front identification in company $Z$}

In response to the call for establishing an animal identification and disease traceability system by the Bureau of Animal Husbandry and Veterinary Medicine in the county, company $\mathrm{Z}$ joined the first group of trial units to establish a relevant traceability system, using the 'company + bases + farmers' development model.

The information platform of company Z's pork traceability system was freely developed by the Hangzhou Agricultural Bureau as part of the information management system on meat quality and safety in Hangzhou province, and it comprises breeding, slaughter, wholesale, and retail (Figure 6).

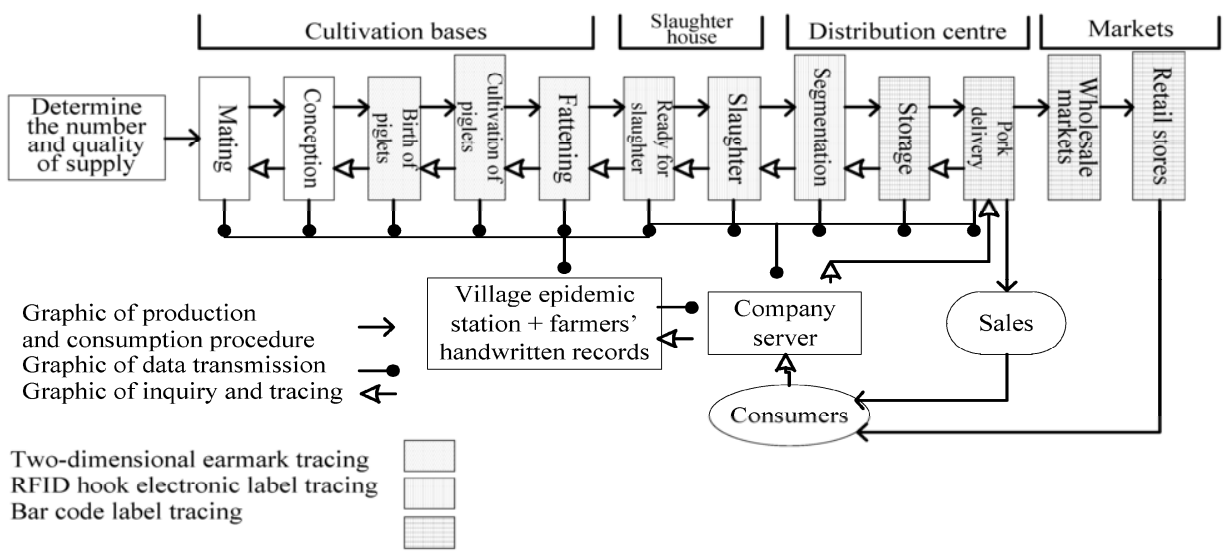

Figure 6. Flow diagram of the pig traceability system in company $Z$

Data source: drawn by the author

The two-dimensional ear mark serves as a major identification method of individual pork, which can be applied freely by the local epidemic station. This ear 
mark type can trace down each pork, and there are two stages in its front identification management.

Stage 1 is from the birth of porklets to pork being ready for slaughter. The company practices collaborative breeding with farmers using the 'company + bases + farmers' model. During the breeding process, porks receive two-dimensional ear marks from the village veterinarians within a certain time after the birth of the porklets. During this process, individual farmers usually keep a handwritten record of information, including on introduction and breeding, whereas farmers at a certain scale record each piece of information through ear mark reading.

Stage 2 covers the processes after slaughter. After slaughtering of pork, company Z conducts purchase at the stated price. Nonlocal clients need to have three certifications - for exiting the county, animal origin, and vehicle disinfection (local clients only need to have certification of animal origin and vehicle disinfection) - to sell pork to company Z.

Qualified pork is put into the sty for slaughter by the staff, and it receives pre-test by the quality control staff of company Z. Pork passing the pre-test rests quietly for 24 hours at company Z, during which an 'ID card' (a small black card with a wireless microwave tracing system) is made for each pork and 'dispatched'. After resting, the pork goes through the quarantine, slaughter, and segmentation production line with 18 links. From the production process to cold chain transportation to the end point, an information file for each piece of pork keeps record of the responsibility of the breeding source and the 18 links including quarantine, similar to an 'ID' profile.

When pork products reach the points of sale, consumers can check relevant information on the pork traceability query machine in the supermarket based on sellers' names and products' certification number on the receipt.

\subsection{Problems of implementing front identification of pig traceability system in three enterprises}

\subsubsection{Willingness to pay}

Company $\mathrm{B}$ is subordinated to the agricultural reclamation system with the pork traceability system as part of the requirement of the product quality traceability system project. Apart from the regulation by the agricultural reclamation system, company B stays committed to the idea of quality elevation of the black pork product as a whole through front identification of the pork traceability system, which guarantees safety of the primary pork product and is responsible to the consumer. Thus, company B shows strong willingness to implement front identification.

With increasing demand for consumer food safety, Company $\mathrm{S}$ began pork traceability in 2007 with the Shandong Standard Cooperative Research Institute. The system's purpose is to improve the product quality and safety level, further enhance the company's competitiveness, and avoid the trade barriers in developed countries. Therefore, company S shows strong willingness to implement front identification.

Company $\mathrm{Z}$ is the first pilot site for implementation of the traceability system. As the system's economic effect is not obvious, the company's willingness to implement front identification needs to be improved. 


\subsubsection{Organization model}

Company B uses the 'company + bases + employees' organization model of front identification implementation, even though the pork breeding business is managed by externally hired personnel with salary. The processes covering the labour room, porklet breeding, and grown-up pork are all under the control of company employees, along with unified fodder management, epidemic prevention and control, and fodder supply in accordance with strict standards. The recording and storage of the pork breeding file from the breeding link is completed by company employees, guaranteeing absolute control of all front breeding links as well as implementation and accuracy of the front identification of the pork traceability process. Moreover, the Bureau of State Farms and Land Reclamation conducts yearly spot tests at company B.

Company S uses the 'company + cooperative + farmers' organization model of front identification implementation. The cooperative was established by Livestock Science \& Technology Co. Ltd. A company S subsidiary with the registered trademark 'Ou De Lai' (ODL). It has 3,500 member farmers and registered capital of 100 million yuan. The cooperative is based on the ODL brand and company S. When the cooperative signs the contract for pork breeding with its members, it pays with share capital as one of the members. The members' investment methods include cash, storehouse, processing equipment, transportation equipment, intellectual property, other property rights excluding labour, credit, name of a natural person, business reputation, and assets with equivalent voucher.

The cooperative's management model has the features of 'six unified links, one ensured part', which includes unified hog house design with standardized breeding, unified supply of pork lets; unified supply of fodder to ensure better quality supply at cheaper price under the unified fodder supply agreement; unified veterinary drug administration and quarantine to prevent disease outbreak with better quarantine; unified technological service that organizes monthly training classes on pork breeding skills since the cooperative's establishment; and unified purchase of fat pork to make the business lucrative for farmers.

Company $Z$ uses the 'company + farmers' organization model of front identification implementation. Famers must meet five standards to be selected: secondary education at least for farmhands; suitability of the hog house and surroundings for pollution-free pork production; design of farmland, orchard, and fish pond to ensure the scale of four porks per acre; relatively stable income flow; and regulation of pollution-free production by the company base.

\subsubsection{Cost and benefit of completing front identification}

In Company $\mathrm{B}$, the cost of completing front identification of the pork traceability system incorporates the following five categories.

Machinery. This includes two computers for Beijing black pork stock base; two computers for Beijing black pork breeding base; one computer for the black pork slaughter shop at the Beijing $5^{\text {th }}$ Meat Processing Plant; one set of servers for the company, data centre, and delivery centre; five additional computers, counter tops, storage racks, and transit cases. All are acquired at 500,000 yuan from the Bureau of State Farms and Land Reclamation with no extra cost.

Information platform development. The unified organization of the Bureau of State Farms and Land Reclamation provides free access for a few years. 
Human resources. The three collection points require an additional five to six people, but the cost can be ignored if the pork traceability system is linked to company management.

Label. This requires 0.03 yuan per paper. Cost of text recording and receipt printing, which is very low, can be omitted.

The black pork product of company B does not go through a drastic price hike because of the front identification of the pork traceability system, thus bringing no significant economic effect so far. However, according to the statistics of the points of sale at each hypermarket and exclusive shop, the sales volume of company B's pork product is on the increase, with the black pork brand taking up a certain market share and a prospect of further increase.

In Company $\mathrm{S}$, the cost of completing front identification of the pork traceability system incorporates the following five categories.

Machinery and human resources. The company is already equipped through former adherence to the Hazard Analysis and Critical Control Points and thus has no additional need in these two categories.

Information platform development. This is provided free under the national ' 863 ' project at Shandong Institute of Standardization.

Label. This requires 0.03 yuan per paper. Text recording and receipt printing is done at very low cost.

Cost of information storage and management.

The pork products of company $\mathrm{S}$ are aimed towards markets both at home and abroad, with the company's brand taking up a certain market share with optimistic prospects of sales. With the increase in consumers' awareness of food safety, company $\mathrm{S}$ commenced cooperative efforts with the Shandong Institute of Standardization in 2007 for implementation of the pork traceability system. It accomplished front identification of the pork traceability system and aimed to further elevate the company's competitiveness to transcend the trade barriers from developed countries.

The management of front identification in company $\mathrm{S}$ can be expanded relatively easily. However, there are still problems: Under the leadership of the leading company, farmers, as the vulnerable group with generally low education, can become overly dependent and inclined to resort to speculation. Moreover, vast coverage of the bases results in incomplete supervision or high supervision cost to the company which is pushed on to farmers."

In Company $\mathrm{Z}$, the cost of completing front identification of the pork traceability system incorporates the following six categories.

Machinery. This costs around 500,000 yuan.

Information platform development. The information management system on meat quality and safety is developed for free by the Hangzhou Agricultural Bureau.

Label. This requires 0.03 yuan per label.

Two-dimensional ear mark. This is provided by the state for free.

Human resources. Veterinarians with contracts with the village are selected through negotiation with the animal husbandry and veterinary medicine technological department in the county (in charge of the whole region).

Paper. Cost of text recording and receipt printing, which is very low, can be omitted.

In response to the call for establishing the animal identification and disease traceability system by the Bureau of Animal Husbandry and Veterinary Medicine in the county, company $\mathrm{Z}$ joined the first group of trial units to establish a relevant 
traceability system. The economic gain is not significant until a certain period of operation, which reduced the company's willingness to implement front identification.

\subsubsection{Benefit allocation}

Company B's employees are in charge of black pork breeding. When short of hands, the company hires labour for front identification of the traceability system, but company employees still supervise them to ensure better quality. The employees are governed by the company's salary system, and the relationship between the two is stable and controlled.

Company S conducts unified purchase of fat pork from the cooperative's member farmers to provide them a decent profit. Of the surplus, the cooperative sets aside $60 \%$ as reserved funds for expanding production, covering deficit, or investing by members. Moreover, it uses $15 \%$ of the annual surplus as a public welfare fund for technological training; cooperative education; and support regarding culture, welfare, and livelihood. When the costs of production, operation, management, service, deficit coverage, reserved funds, and public welfare funds are taken out of the surplus, the member assembly decides on the refund based on the trade volume between members and the cooperative. The total refund amount should be at least $80 \%$ of the distributed surplus, while the remainder is rationed to the members' recorded accounts according to their contributions to the investment and reserved funds, as well as the per capita amount of direct national subsidies or donations from other parties to the cooperative.

Company $\mathrm{Z}$ is committed to sharing the profit and risk; providing unified fodder; ensuring proper vaccination, disinfection, and healthcare procedures; providing training and instruction on breeding and management skills; increasing the ration of fodder sold on credit with yearly increase in pork raising; and uniform settling of the account at delivery. The company sets a conservation price for pork purchase, allowing farmers to sell pork through their own channels or uniformly to the company (at conservation plus bonus price) when the market is at its peak, or to sell it at the conservation price to the company when the market is at its low.

However, farmers might forge or leave out information in the front identification process for the pursuit of individual interest, leading to an unstable relationship between the relevant parties.

\subsubsection{Expansion of front identification management of the pork traceability system}

When it comes to expansion of the management, company B sticks to the policy of independent breeding and breeding, using the organization model of 'company + bases + employees' for front identification implementation, which gives control of all the breeding links to company employees for unified management. The employees are better educated than regular farmers, and speculation of individual farmers can be nipped in time to ensure the completeness and authenticity of front identification information, thus cutting the surveillance cost dramatically. Company B, an affiliate of the agricultural reclamation system, has received decent funding and technological support from the higher authority; thus, it saved a large amount of investment cost.

However, the 'company + bases + employees' model poses some difficulties for expansion. The bases have a limited breeding field in Beijing, of which the scale is too small to drive the income increase for individual farmers and reach a desirable level of technology. If the breeding field is expanded, to different areas even, the small number 
of employees can cause the management to easily fall apart, giving rise to incorrect front identification information among other problems. The company will find it hard to bear the additional heavy surveillance cost for complete management.

Coding rules of the front identification of company B's pork traceability system are formulated by the company itself, instead of following the national standard. This makes it difficult to ensure synergy with the information base of the follow-up slaughtering and processing companies, creating obstacles for expansion. The slaughter procedure of company B is outsourced to the Beijing 5th Meat Processing Plant, and the coding problem might cause issues in the alignment of the front and rear identification information of the pork traceability system, leading to dislocation of the identification of the system.

The management model in company $\mathrm{Z}$ is difficult to expand. Even though the company has signed a contract with farmers from the bases, there is still a large amount of extra cost for farmers to ensure standardized breeding. Farmers still can take initiative in selling pork and refuse to sell to the company. Company $\mathrm{Z}$ brings no punishment to the farmers, leaving them with the mindset of having the ability the take a chance and sell pork without sticking to the contract.

\subsection{Results of case comparison}

Table 1 displays the comparison and differences in the front identification of the three companies. According to the case study of the three companies, the differences of the front identification implementation level lies in the aspects including the organization model of the front identification implementation subject, region, the scale of the farmer, education level of the farmer, economic level of the company, the cost and benefit of the company and farmer, the additional technological support to the farmer from the company, the risk expectation of the farmer, the company's supervision system on the farmer and the identification method.

Table 1 The comparison of front identification implemented in three companies

\begin{tabular}{|c|c|c|c|}
\hline Items & Company B & Company S & Company Z \\
\hline $\begin{array}{l}\text { If possible to trace to the } \\
\text { front cultivation link }\end{array}$ & Yes & Partly & Partly \\
\hline Business type & $\begin{array}{l}\text { Cultivation } \\
\text { (independently) }\end{array}$ & $\begin{array}{l}\text { Group company -unified } \\
\text { production, supply and } \\
\text { sales (the cultivation is } \\
\text { still outsourced) }\end{array}$ & $\begin{array}{l}\text { Slaughter and process } \\
\text { company (with the } \\
\text { cultivation } \\
\text { outsourced) }\end{array}$ \\
\hline $\begin{array}{l}\text { Organization subject of } \\
\text { implementation subject }\end{array}$ & $\begin{array}{l}\text { Company }+ \text { bases }+ \\
\text { employees }\end{array}$ & $\begin{array}{l}\text { Company }+ \text { cooperative }+ \\
\text { farmers }\end{array}$ & $\begin{array}{l}\text { Company }+ \text { bases }+ \\
\text { farmers }\end{array}$ \\
\hline $\begin{array}{l}\text { Vertical cooperation level } \\
\text { of the organization subject }\end{array}$ & Tight & Half-tight & Loose \\
\hline $\begin{array}{l}\text { Reporter of the front } \\
\text { identification information }\end{array}$ & Employees & Staff from the cooperative & $\begin{array}{l}\text { Epidemic prevention } \\
\text { workers from the } \\
\text { village }\end{array}$ \\
\hline $\begin{array}{l}\text { Subject of front } \\
\text { identification information } \\
\text { record }\end{array}$ & Employees & Cooperative members & Farmers \\
\hline $\begin{array}{l}\text { Education level of the } \\
\text { subject recording the } \\
\text { information }\end{array}$ & College & $\begin{array}{l}\text { Vary from primary to } \\
\text { high school }\end{array}$ & $\begin{array}{l}\text { Vary from primary to } \\
\text { high school }\end{array}$ \\
\hline
\end{tabular}




\begin{tabular}{|c|c|c|c|}
\hline $\begin{array}{l}\text { Subject's willingness to } \\
\text { record the information }\end{array}$ & Willing to & $\begin{array}{l}65 \% \text { of the members find } \\
\text { it necessary, while the rest } \\
\text { don't }\end{array}$ & $\begin{array}{l}\text { A small part of the } \\
\text { farmers are willing to }\end{array}$ \\
\hline $\begin{array}{l}\text { Technological instruction } \\
\text { from the company }\end{array}$ & Yes & Yes & Yes \\
\hline $\begin{array}{l}\text { Boar, veterinary medicine } \\
\text { and fodder from the } \\
\text { company }\end{array}$ & Yes & No & Partly \\
\hline $\begin{array}{l}\text { Management model of the } \\
\text { front identification }\end{array}$ & $\begin{array}{l}\text { Unified } \\
\text { management }\end{array}$ & Not sure if it is unified & $\begin{array}{l}\text { Not sure if it is } \\
\text { unified }\end{array}$ \\
\hline $\begin{array}{l}\text { Carrier of the front } \\
\text { identification }\end{array}$ & Earmark + ink mark & RFID earmark & $\begin{array}{l}\text { Two-dimensional } \\
\text { earmark }\end{array}$ \\
\hline Type of cost & $\begin{array}{l}\text { Internal } \\
\text { management cost }\end{array}$ & $\begin{array}{l}\text { Transaction and contract } \\
\text { cost }\end{array}$ & $\begin{array}{l}\text { Transaction and } \\
\text { contract cost }\end{array}$ \\
\hline Transaction cost & Low & Average & High \\
\hline Organization cost & High & High & Low \\
\hline Cooperation & Strong & Average & Low \\
\hline Stability & Strong & Average & Low \\
\hline Motivation for adjustment & $\begin{array}{l}\text { Organization } \\
\text { planning }\end{array}$ & $\begin{array}{l}\text { Negotiation, multi-player } \\
\text { game }\end{array}$ & Market supply \\
\hline Risk on farmers & Low & Average & High \\
\hline $\begin{array}{l}\text { The stability of farmers' } \\
\text { income }\end{array}$ & High & Average & Low \\
\hline $\begin{array}{l}\text { Farmers motivated by the } \\
\text { whole cause }\end{array}$ & Few & Many & Many \\
\hline $\begin{array}{l}\text { Level of the organization, } \\
\text { socialized labor division } \\
\text { and intensive usage of } \\
\text { resources of the pig } \\
\text { industry }\end{array}$ & Low & High & Average \\
\hline $\begin{array}{l}\text { Completeness of the front } \\
\text { identification information }\end{array}$ & Complete & Incomplete & Incomplete \\
\hline $\begin{array}{l}\text { Authenticity of the front } \\
\text { identification information }\end{array}$ & Authentic & Not sure & No sure \\
\hline $\begin{array}{l}\text { Supervision model of the } \\
\text { company }\end{array}$ & Cyclic & No & Spot check \\
\hline $\begin{array}{l}\text { The reward and } \\
\text { punishment system of the } \\
\text { company }\end{array}$ & Yes & No & No \\
\hline Company location & Central & East & West \\
\hline Pig source & Company & Company + purchase & Purchase \\
\hline $\begin{array}{l}\text { The subjects in the front } \\
\text { and rear links }\end{array}$ & One-to-one & Many-to-one & Many-to-many \\
\hline Company scale & Medium & Large & Small \\
\hline $\begin{array}{l}\text { Difficulty of } \\
\text { implementing the front } \\
\text { identification }\end{array}$ & Easy & Difficult & Difficult \\
\hline $\begin{array}{l}\text { Implementation level of } \\
\text { the front identification }\end{array}$ & Good & Average & Poor \\
\hline
\end{tabular}




\section{Conclusions}

(1) The organization model of front identification of pig traceability system plays an important role in front identification management. "Company + bases + employees" is the most conducive to the completeness of the front identification, but also very difficult for expansion.

Among the three companies, the front identification implementation of company B's pig traceability system is relatively better than the other two, due to the "company + bases + employees" model adopted in company B, providing a closer vertical cooperation of the implementation subject and exerting stricter restriction on employees to complete the front identification thoroughly, and the operation throughout the cultivation process uniformly and normatively. Moreover, the company possesses employees with higher level of education, so as to fill in and upload the cultivation information and date correctly and timely, without reporting false information or incapability in handling the equipment. The only shortcoming lies in the synergy system between the front and rear identification, which can be compensated from the practice of company S. The model used in company S, however, creates some difficulties for expansion, since its bases are only located in Beijing with relatively small scale, and limited ability to boost the income and skills of the individual farmers. Once the scale of pig cultivation expands to even different regions, the lack of employees will give rise to porous management, with the abovementioned problems such as fake front identification information. The complete management requires large amount of extra supervision cost, which can be tricky for the company.

(2) "Company + cooperative + farmers" is relatively suitable for expansion among the models of front identification management.

Company $\mathrm{S}$ has the better front identification implementation in comparison with company Z. The model "company + cooperative + farmers" adopted by company S might has the principal-agent problem, but the front identification can still be improved with stricter management. What's more, farmers raising pigs in China are mostly disperse with small scale, and this model can help introduce more farmers of this kind into the front identification of the pig traceability system, therefore it is regarded as more suitable for expansion.

(3) Apart from the organization model, there are multiple factor affecting the front identification implementation of China's traceability system, including the education level of the implementation subject, identification technology and method, the company scale, the traceability notion of the heads of the company, and the location of the company as important factors, directly proportional to the implementation level of the front identification of pig traceability system.

A tight organization model of the implementation subject of the front identification, high education level of the farmers and heads of the company, a better pig traceability notion, an identification method with advanced technology and company at large scale are all the requirements of a complete front identification of the pig traceability system.

The promotion of front identification of pig traceability system is a work requiring incremental effort. Presently the farmers and companies lack relevant understanding, and based on the Chinese national condition, starting from the easier part, and giving a leading role to the companies as demonstration to influence the whole region eventually. At the same time, as a developing country with a large population, the 
implementation of pig traceability system not only improves the level of food safety in China, but also provides reference for other development in the world.

\section{Acknowledgments}

This research was supported by Ministry of Education Humanities and Social Sciences Planning Foundation of China under Grant Number 20YJA630004, and National Natural Science Foundation of China under Grant Number 71772099.

\section{References}

[1] Wu, L., Wang, S.H., Zhu, D. (2015), "Consumer preference for traceability food: A joint analysis based on selection”, Journal of Agrotechnical Economics, Vol. 4, pp. 45-53.

[2] Manos, B. and Manikas, I. (2010), "Traceability in the Greek fresh produce sector: Drivers and constraints", British Food Journal, Vol. 112 No. 6, pp. 640-652.

[3] Zhang, C., Bai, J. and Wahl, T.I. (2012), "Consumers' willingness to pay for traceable pork, milk, and cooking oil in Nanjing, China", Food Control, 2012, 27(1):21-28.

[4] Riden, C.P. and Bollen, A.F. (2007), "Agricultural supply system traceability, part II: Implications of packhouse processing transformations”, Biosystems Engineering, Vol. 98 No. 4, pp. 401-410.

[5] Van Rijswijk, W., Frewer, L.J., Menozzi D. and Faioli, G. (2008), "Consumer perceptions of traceability: A cross-national comparison of the associated benefits", Food Quality \& Preference, Vol. 19 No. 5, pp. 452-464.

[6] Dabbene, F., Gay, P. and Tortia, C. (2014), "Traceability issues in food supply chain management: A review”, Biosystems Engineering, Vol. 120 No. 3, pp. 65-80.

[7] Honghua, C. and Zhihong, T. (2016), "Cost analysis and pricing policies for enterprises implementing traceability system in China”, China Agricultural University Journal of Social Sciences Edition, Vol. 33 No. 4, pp. 116-121.

[8] Sumner, D.A. and Pouliot, S. (2010), "Traceability, product recalls, industry reputation and food safety", European Review of Agricultural Economics, Vol. 40 No. 1, pp. 121-142.

[9] Pouliot, S. and Sumner, D.A. (2013), "Traceability, recalls, industry reputation and product safety", European Review of Agricultural Economics, Vol. 40 No. 1, pp. 121-142.

[10] Meuwissen, M.P.M., Velthuis A.G.J., Hogeveen H. and Huirne, R.B.M. (2003), "Traceability and certification in meat supply chains", Journal of Agribusiness, Vol. 21 No. 2, pp. 167-181.

[11] Schulz, L.L. and Tonsor, G.T. (2010), "Cow-calf producer preferences for voluntary traceability systems”, Journal of Agricultural Economics, Vol. 61 No. 1, pp. 138-162.

[12] Honghua, C., Zhihong T., Fen X. (2019), "What are Cost Changes for Produce Implementing Traceability Systems in China? Evidence From Enterprise A ”, Applied Economics, Vol. 51 No. 7, pp. 687-697.

[13] Zheng, S., Xu, P., Wang, Z. and Song, S. (2012), "Willingness to pay for traceable pork: Evidence from Beijing, China", China Agricultural Economic Review, Vol. 4 No. 2, pp. 200-215.

[14] Wu, L., Wang, H., Zhu, D., Hu, W. and Wang, S. (2016), "Chinese consumers' willingness to pay for pork traceability information-the case of Wuxi”, Agricultural Economics, Vol. 47 No. 1, pp. 71-79.

[15] Ying, R., Hou, B., Chen, X. and Xu, L. (2016), "An analysis of the consumer's willingness to pay for information attributes of traceable food: A case of pork", Chinese Rural Economy, Vol. 11, pp. 44-56.

[16] Zhou, J., Chen, X. and Liu, Q. (2012), "Behavior, performance and policy choice of quality safety traceability in pork slaughtering and processing enterprises -- An empirical analysis based on Zhejiang”, Journal of Agrotechnical Economics, Vol. 8, pp. 29-37.

[17] Wu, L., Xu, L., Zhu, D., Liu, X. (2014), "Study of the main factors affecting enterprises' investment on food traceability system: Perspective from logistic model with a penalty function", Management Review, Vol. 26 No. 1, pp. 99-108.

[18] Schroeder, T.C. and Tonsor, G.T. (2012), "International cattle ID and traceability: Competitive implications for the US", Food Policy, Vol. 37 No. 1, pp. 31-40.

[19] Chen, G.P., Qin, W.J., Ding, J., Wan, M.C., Guo, L.F. and Wang, W.S. (2017), "Designing and validation of the remote monitoring system for pigs' survival based on IoT technology", Scientia Agricultura Sinica, Vol. 50 No. 5, pp. 942-950. 
[20] Wu, X., Lü, B.B, Wang, J.B., Jiang, W., Li, P., Wu, G.G. and Tang, X.M(2017). "Development and application of pork traceability system based on SNP markers", Food Science, Vol.38 No.24,pp. 278-282.

[21] Du, Z.J.(2010), "Under the utility maximization of buckets effect", China Collective Economy, No.28, pp. $76-77$

[22] Graneheim, U.H. and Lundman, B. (2004), "Qualitative content analysis in nursing research: concepts, procedures and measures to achieve trustworthiness", Nurse Education Today, Vol. 24 No. 2, pp. 105-112.

[23] Lincoln, Y.S. and Guba, E.G. (1985), Naturalistic Inquiry, Sage Publications, Thousand Oaks, CA.

[24] Morse, J.M., Barrett, M., Mayan, M., Olson, K. and Spiers, J. (2002), "Verification strategies for establishing reliability and validity in qualitative research", International Journal of Qualitative Methods, Vol. 1 No. 2, pp. 1-19. 